\title{
Correction to: Bioavailability of subcutaneous and intramuscular administrated buprenorphine in New Zealand White rabbits
}

Raad Askar ${ }^{1}$, Elin Fredriksson², Elin Manell², Mikael Hedeland ${ }^{3,4}$, Ulf Bondesson ${ }^{3,4}$, Simon Bate ${ }^{5}$, Lena Olsén ${ }^{2}$ and Patricia Hedenqvist ${ }^{2^{*}}$

\section{Correction to: BMC Vet Res. 16, 436 (2020)}

\section{https://doi.org/10.1186/s12917-020-02618-7}

The original article [1] contained an error in the naming of the boxplots in Fig. 4. This has since been corrected.

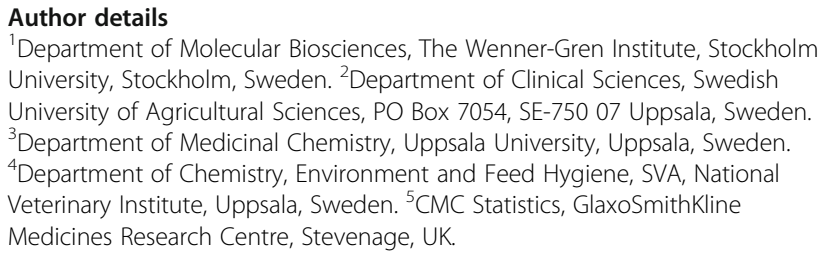

Published online: 16 April 2021

\section{Reference}

1. Askar R, Fredriksson E, Manell E, Hedeland M, Bondesson U, Bate S, et al.

Bioavailability of subcutaneous and intramuscular administrated

buprenorphine in New Zealand white rabbits. BMC Vet Res. 2020;16(1):436.

https://doi.org/10.1186/s12917-020-02618-7.

The original article can be found online at https://doi.org/10.1186/s12917020-02618-7.

* Correspondence: patricia.hedenqvist@slu.se

${ }^{2}$ Department of Clinical Sciences, Swedish University of Agricultural Sciences, PO Box 7054, SE-750 07 Uppsala, Sweden

(c) The Author(s). 2021 Open Access This article is licensed under a Creative Commons Attribution 4.0 International License, which permits use, sharing, adaptation, distribution and reproduction in any medium or format, as long as you give appropriate credit to the original author(s) and the source, provide a link to the Creative Commons licence, and indicate if changes were made. The images or other third party material in this article are included in the article's Creative Commons licence, unless indicated otherwise in a credit line to the material. If material is not included in the article's Creative Commons licence and your intended use is not permitted by statutory regulation or exceeds the permitted use, you will need to obtain permission directly from the copyright holder. To view a copy of this licence, visit http://creativecommons.org/licenses/by/4.0/. The Creative Commons Public Domain Dedication waiver (http://creativecommons.org/publicdomain/zero/1.0/) applies to the data made available in this article, unless otherwise stated in a credit line to the data. 